\title{
Evaluation of Physicochemical Characteristics of Groundwater from Selected Areas in Unguwa Uku, Kano Metropolitan, Northwestern Nigeria
}

\author{
Sadiq Abdurrahman Abubakar Shawai, ${ }^{1, ~ *, ~ R a b i ’ u ~ M u s a ~ K u t a m a ², ~ B i l k i s u ~ B e l l o ~ A b u b a k a r ², ~}$ \\ Jafaru Muazu ${ }^{3}$ \\ ${ }^{1}$ Department of Chemistry, School of Science Education, Sa'adatu Rimi College of Education, Kumbotso, Nigeria \\ ${ }^{2}$ Department of Biology, School of Science Education, Sa'adatu Rimi College of Education, Kumbotso, Nigeria \\ ${ }^{3}$ Department of Geography, College of Advance and Remedial Studies, Tudunwada, Nigeria
}

Email address:

Sadiqaashawai2020@yahoo.com (S. A. A. Shawai)

*Corresponding author

\section{To cite this article:}

Sadiq Abdurrahman Abubakar Shawai, Rabi’u Musa Kutama, Bilkisu Bello Abubakar, Jafaru Muazu. Evaluation of Physicochemical Characteristics of Groundwater from Selected Areas in Unguwa Uku, Kano Metropolitan, Northwestern Nigeria. International Journal of Biomedical Materials Research. Vol. 6, No. 1, 2018, pp. 8-12. doi: 10.11648/j.ijbmr.20180601.12

Received: October 26, 2017; Accepted: November 25, 2017; Published: January 19, 2018

\begin{abstract}
Present investigation was carried out on groundwater in Unguwa Uku for water quality parameters during October, 2016. Parameters such as total hardness (TH), alkalinity, electrical conductivity (EC), turbidity, $\mathrm{pH}$, temperature, chloride, calcium, free $\mathrm{CO}_{2}$, suspended solids (SS), total suspended solids (TSS), total dissolve solids (TDS), colour, and odour were analyzed from five locations. The analysis were carried out using standard analytical methods. The analysis of data reveals that, the value of free $\mathrm{CO}_{2}$ ranges from 9- $104 \mathrm{mg} / \mathrm{L}, 36.05-72.10 \mathrm{mg} / \mathrm{L}$ for Calcium, 2-13 NTU for turbidity, 583.59$2065.03 \mathrm{mg} / \mathrm{L}$ for total hardness 7.1-8.3 for $\mathrm{pH}, 21.7-23.4^{\circ} \mathrm{C}$ for temperature, 202-970 mg/L for TDS, $250-305 \mathrm{mg} / \mathrm{L}$ for alkalinity, $405-1939 \mu \mathrm{S} / \mathrm{cm}$ for conductivities, $5 \mathrm{TCU}$ for colour, $111.70-659.51 \mathrm{mg} / \mathrm{L}$ for suspended solids, 669.03$1255.51 \mathrm{mg} / \mathrm{L}$ for total suspended solids, $106.57-296.10 \mathrm{mg} / \mathrm{L}$ for chloride. The results obtained revealed that, the values of alkalinity, TDS, TSS, SS, pH, temperature, colour, odour, free $\mathrm{CO}_{2}$, and concentrations of Calcium of the water samples analyzed are within the acceptable limits set by World Health Organization (WHO) and Nigerian Standards for Drinking Water Quality (NSDWQ) for the drinking water. The values of electrical conductivity and total hardness are above the maximum permissible limits and may have adverse effects on the human health of the study area. However, not all the values of turbidity and chloride in the samples are within the acceptable limits of WHO and NSDWQ in the drinking water. This paper also recommended that, government and non-governmental agencies should make reasonable effort to control, regulate and educate the people in the study area for proper disposal of domestic effluents.
\end{abstract}

Keywords: Physicochemical Parameters, Conductivity, Analytical Methods, Total Hardness, Suspended Solid

\section{Introduction}

Man's activities on earth are significantly influenced by availability of and accessibility to the quality water for domestic, agricultural as well as other purposes. Clean water is fundamental to the health and well-being of the entire society [1]. Water as an essential commodity today faces certain challenges in terms of its supply and quality. Reference [1] Observed that, the condition of water supply for human consumption and other purposes in most developing countries such as Nigeria is in pitiful state. The quality of water is of vital importance to making since it is directly linked with human health [2]. According to [2] the quality of groundwater is equally important to its quantity due to the suitability of water for various purposes which include drinking, domestic, industrial and agricultural purposes. The quality of groundwater in a particular area is a function of chemical, physical and biological characteristics. The variation of groundwater quality in a given area is 
influenced by geological formations and anthropogenic activities [2]. Water has enormous potentials for spreading ill health and even death if its quality is not properly assessed and state of use been assured [3-4]. [3-5] Reported that, 10 million people die because of drinking contaminated water or water off less quality every year. These are the factors why water quality studies have been receiving a special consideration at several points in time by different scholars and researchers [3].

The study area (Unguwa Uku) is an area surrounded by different sources of contamination which include; large domestic effluents channels, Nigeria National petroleum cooperation (NNPC) depot, abattoir, soak away, pit latrines motor Park as well as geological nature of the study area. It is essential to analyze the quality of the groundwater in this area and monitor it with a view to finding solution to the health problems associated with drinking water in an area. This research aims to establish the levels of some physicochemical parameters in groundwater in Unguwa Uku, Tarauni local government area of Kano Metropolitan, Nigeria.

\section{Materials and Methods}

\subsection{Description Area}

Unguwa Uku is an area located in Tarauni local government area of Kano state, Nigeria. It lies between $11.9666^{\mathrm{O}} \mathrm{N}$ longitude and $8.5639^{\circ} \mathrm{E}$ latitude [7]. It's the most densely populated within the local government. It shares boundaries with Naibawa to the south, Kundila housing estate to the north, Hotoro Walawai to the east and Yarakwa and Darmanawa to the west.

\subsection{Sampling Points}

Water samples were collected from five points designated as $\mathrm{U}_{1}-\mathrm{U}_{5}$ [8]. Samples were collected at Yan awaki $\left(\mathrm{U}_{1}\right)$, Gangaran Unguwa Uku $\left(\mathrm{U}_{2}\right)$, Filin Kashu/ Kauyen Alu $\left(\mathrm{U}_{3}\right)$, Kauyen Nono $\left(\mathrm{U}_{4}\right)$ and Unguwa Uku Cikin gari $\left(\mathrm{U}_{5}\right)$.

\subsection{Sample Collection}

Five samples of borehole and well water in the ratio of $3: 2$ were collected from various areas of Unguwa Uku, Tarauni local government of Kano State using clean new polyethene plastic containers which were covered with black polyethene bags to prevent growth of algae. The $\mathrm{pH}$ and temperature were measured immediately and sample was stored at a temperature below $4^{\circ} \mathrm{C}$, in order to prevent the growth of microorganisms [6].

\subsection{Physicochemical Analysis}

The samples were analyzed for major physical and chemical water quality parameters like TDS, TH, EC, pH, temperature, alkalinity, odour, colour, turbidity, Calcium, as described in standard methods for the examination of water and waste water of American public Health Association [9].

The temperature and $\mathrm{pH}$ of the water samples were determined at the point of sampling using portable hand-held mercury in glass thermometer. Conductivity and total dissolved solids were determined using a digital conductivity matter (HARCH model) [6]. The total hardness, total alkalinity, turbidity, the concentrations of chloride, and other parameters were determined by the standard methods of water and waste water [9].

\section{Results}

The concentration of some physicochemical parameters in water samples from the five sampling point in Unguwa Uku are presented in table 1 below:

Table 1. Results of Physicochemical parameters analyzed.

\begin{tabular}{|c|c|c|c|c|c|c|}
\hline $\mathbf{S} / \mathbf{N}$ & Parameters Samples & $\mathrm{U}_{1}$ & $\mathbf{U}_{2}$ & $\mathbf{U}_{3}$ & $\mathbf{U}_{4}$ & $\mathbf{U}_{5}$ \\
\hline 1. & $\mathrm{pH}$ & 7.1 & 8.0 & 7.2 & 7.8 & 8.3 \\
\hline 2. & Temperature $\left({ }^{\circ} \mathrm{C}\right)$ & 23.1 & 22.7 & 22.8 & 21.7 & 23.4 \\
\hline 3. & Conductivity $(\mu \mathrm{S} / \mathrm{CM})$ & 1401 & 1939 & 1018 & 1266 & 405 \\
\hline 4. & TDS (mg/L) & 697 & 970 & 309 & 596 & 202 \\
\hline 5. & Alkalinity (mg/L) & 270 & 295 & 250 & 270 & 305 \\
\hline 6. & Hardness (mg/L) & 1616.1 & 2065.03 & 1548.77 & 1795.60 & 583.59 \\
\hline 7. & Turbidity (NTU) & 13 & 7 & 4 & 2 & 3 \\
\hline 9. & Odour & Obj & Obj & Onobj & Onobj & Onobj \\
\hline 10. & Chloride (mg/L) & 106.57 & 117.30 & 296.1 & 118 & 112.51 \\
\hline 11. & Calcium (mg/L) & 72.10 & 46.87 & 36.05 & 50.47 & 43.30 \\
\hline 12. & Free $\mathrm{CO}_{2}(\mathrm{mg} / \mathrm{L})$ & 104 & 9 & 10 & 14 & 23 \\
\hline 13. & TSS (mg/L) & 933.01 & 1081.7 & 806.80 & 1255.51 & 669.03 \\
\hline 14. & $\mathrm{SS}(\mathrm{mg} / \mathrm{L})$ & 236.01 & 111.70 & 497.80 & 659.51 & 467.03 \\
\hline
\end{tabular}

\section{Discussion}

\subsection{Free Carbon Dioxide}

The value of free $\mathrm{CO}_{2}$ ranges from 9- $104 \mathrm{mg} / \mathrm{l}$. The maximum value of $104 \mathrm{mg} / \mathrm{l}$ was recorded in the sampling point $U_{1}$ and minimum value of $9 \mathrm{mg} / \mathrm{l}$ was recorded in the sampling point $U_{2}$. This may be depends upon alkalinity and hardness of water body [10].

\subsection{Odour}

It is evident from the Tables that the water samples possess 
some perceived odour that was not quantified in this study. The occurrence of odour was probably associated with the presence of inorganic or organic contaminants in water. Related to taste, a strong odour from water for consumption will obviously cause revulsion or rejection on the part of the consumer [11].

\subsection{Electrical Conductivity (EC)}

Electrical conductivity is a measure of water capacity to convey electric current [12]. The mobility of ions in solution can be seen to be closely related with the total alkalinity [13]. EC also signifies the amount of total dissolved salts [12]. The EC values were found higher at $\mathrm{U}_{2}$ sampling point with value of $1939 \mu \mathrm{S} / \mathrm{cm}$. Hence the relatively higher values may be associated to concentrated dissolved salts as a result of human activities [13]. In this study, the electrical conductivity was generally higher than the maximum permissible limit of $1000 \mu \mathrm{s} / \mathrm{cm}$ of [14] in all the water samples with exception of sample from $\mathrm{U}_{5}$.

\section{4. $\mathrm{pH}$ and Total Alkalinity (TA)}

$\mathrm{pH}$ is a term used universally to express the intensity of the acid or alkaline condition of a solution [12]. Most of the water samples are slightly alkaline due to presence of carbonates and bicarbonates [12]. The $\mathrm{pH}$ values of water samples varied between 7.1-8.3 and were found within the limit prescribed by $[14,15]$. Total alkalinity values for all the investigated samples ranges from $250-305 \mathrm{mg} / \mathrm{L}$ with higher value at $\mathrm{U}_{5}$ sampling site. Alkaline water is known as safe, but it has the state of quality to produce side effects [16]. It also affect the consumers by reducing the stomach acid which may likely cause problems to those with low levels of stomach acid [16].

\subsection{Temperature}

Temperature is one of the most essential parameters of water and has a significant of growth and activity of ecological life and also greatly affects the solubility of oxygen in water [17]. The results shown that the values of temperature varied between $21.7-23.4^{\circ} \mathrm{C}$.

\subsection{Total Hardness (TH) and Calcium}

Hardness is the measure of the capacity to produce leather with soap and detergent [18]. It is one of the very important properties of groundwater from utility point of view for different purposes $[12,18]$. Hardness of water depends upon the amount of calcium or magnesium salts or both [12]. The hardness values shown range from $583.59 \mathrm{mg} / \mathrm{L}-2065.03$ $\mathrm{mg} / \mathrm{L}$. The higher value of $2065.03 \mathrm{mg} / \mathrm{L}$ was recorded at $\mathrm{U}_{2}$, while $\mathrm{U}_{5}$ has the lowest value of $583.59 \mathrm{mg} / \mathrm{L}$. Calcium is mainly the micronutrient which present in an aquatic environment. Calcium causes both carbonate and noncarbonate hardness of water [19]. The average value of calcium in study area of river varies from $36.05-72.10 \mathrm{mg} / \mathrm{L}$, maximum value of $72.01 \mathrm{mg} / \mathrm{L}$ is at $\mathrm{U} 1$ and minimum value of $36.05 \mathrm{mg} / \mathrm{L}$ is at $U_{3}$ which was within the acceptable limit recommended by $[14,15]$.

\subsection{Colour}

The colour for all the samples were found to be 5TCU which is within $[14,15]$ permissible limit. According to Ayeni and Bernard [11] colour in drinking-water is usually due to the presence of colour organic matter (primarily humic and fulvic acids) associated with the humus fraction of soil or the presence of iron and other metals, either as natural impurities or as corrosion products.

\subsection{Chloride}

Chloride in drinking water originates from natural sources, sewage and industrial effluents [20]. Chloride does not pose a health hazard to humans and the principal consideration is in relation to palatability [13]. From the results obtained, the concentrations of the chloride in all the water samples were below the NSDWQ [14] and EPA [21] maximum permissible limit of $250 \mathrm{mg} / \mathrm{L}$ except $\mathrm{U}_{3}(296.10 \mathrm{mg} / \mathrm{L})$. High chloride concentrations above the prescribed limit of $250 \mathrm{mg} / \mathrm{L}$, can give rise to detectable taste in water.

\subsection{Turbidity and Total Dissolved Solids (TDS)}

Turbidity is the measurement of the cloudiness of water. Water cloudiness is caused by material suspended in water [22]. The increase of turbidity of water results in interference of the penetration of light [23]. The values of turbidity from the table above varies between 2-13 NTU which means that $60 \%$ of the water supply from the boreholes and wells are within the NSDWQ [14] and WHO [15] maximum permissible limit of 5NTU. Total dissolved solids indicate the salinity behavior of groundwater [12]. Environmental Protection Agency, Ghana (2002) as quoted in Saana et al., [24] reported that, TDS in drinking water is associated with natural sources, sewage, industrial wastewater, urban-runoff, and chemicals used in water treatment process. Water containing more than $500 \mathrm{mg} / \mathrm{L}$ of TDS is not considered desirable for drinking water supplies, but in unavoidable cases $1500 \mathrm{mg} / \mathrm{L}$ is also allowed [12]. The TDS values ranged between $202-970 \mathrm{mg} / \mathrm{L}$. The results presented in table above indicated that, only $40 \%$ of the samples falls below the desirable limit of $500 \mathrm{mg} / \mathrm{L}$.

\subsection{Suspended Solids and Total Suspended Solids}

Total suspended solids of water depend on suspended particles of soil, silt and is directly related to the turbidity of water [25]. The maximum and minimum values of $1255.51 \mathrm{mg} / \mathrm{L}$ and $669.03 \mathrm{mg} / \mathrm{L}$ were recorded at $\mathrm{U}_{4}$ and $\mathrm{U}_{5}$ respectively. The results obtained from the samples analyzed, shown that the values of suspended solids varies between $111.70-659.51 \mathrm{mg} / \mathrm{L}$. The high value was recorded from $\mathrm{U}_{4}$ sampling site.

\section{Conclusion}

The result obtained shows that the alkalinity, TDS, $\mathrm{pH}$, 
temperature, TSS, SS colour, odour, free $\mathrm{CO}_{2}$, concentration for calcium and chloride average values of the water samples analyzed are within the acceptable limits set by WHO [15, 26] and NSDWQ [14] for the drinking water, on the other hand, the mean values of EC, and hardness are above the maximum permissible values and may have adverse effect on human health of the study area. Nevertheless, not all the values of turbidity in water sample are within the acceptable limits set by WHO and NSDWQ in drinking water. Thus, the drinking water in this study area, as not as safe as is generally believed, because some of the parameters analyzed are above the maximum permissible limit set by WHO and NSDWQ in drinking water.

\section{Recommendations}

This research recommended that, government at all levels should provide a scientifically well equipped laboratory for determining the quality of water, environmental agencies both government and non-governmental should make a reasonable effort to control, regulate and educate the community on indiscriminate waste disposal from domestic and industries within the study area, proper disposal or recycling of domestic and industrial waste, heating the water before use can reduce the concentration of the hardness, urban planning authority should provide a proper way for soak away and pit latrines construction, also further research should be carried out to assess the level of some parameters, more especially microbial and heavy metals.

\section{Acknowledgements}

The authors are extremely thankful to Auwalu Musa of Tamburawa water treatment plant for physical and chemical analysis and Dr. Garba Alhaji Adamu the Head of department, science laboratory technology, Kano state polytechnic for consultation throughout the research.

\section{References}

[1] A. H. Kwaru, M. Y. Adam and H. I. Mukhtar (2016). Impact of spatio-temporal Variation in Water Quality to Agricultural Land use at River Challawa Area Kano State. Kano Journal of Science Education, 11 (1).

[2] B. S. Badmus, V. C. Ozebo, O. A. Idowu, S. A. Ganiyu and O. T. Olurin (2014). Groundwater Assessment of Hand dug Wells Around Open Landfill in Ibadan Metropolis for Domestic and Irrigation Purposes. Journal of Water Resources and Protection, 6, 1412-1424.

[3] Abdullahi U. I. and Indabawa I. I. (2012). Study on Physicochemical Parameters and Heavy Metals ( $\mathrm{Pb}, \mathrm{Fe}, \mathrm{Mn})$ Concentrations of tap Water in Dutse, Jigawa State, Nigeria. Bayero Journal of Pure and Applied Science, 5 (2): 89-92.

[4] Brown M. (1991). A practical guide to environment $2 \mathrm{nd}$ ed.

[5] WHO (2004). Chemical and physical standard. Standards for drinking water quality.
[6] Saeed M. D. and Mahmoud A. M. (2014). Determination of some Physicochemical Parameters and some Heavy Metals in Boreholes from Fagge L. G. A. of Kano Metropolis Kano State -Nigeria. World Journal of Analytical Chemistry, 2 (2): 42-46.

[7] http://en.m.wikipedia.org/wiki/Tarauni.

[8] J. C. Akan, M. T. Abbagambo, Z. M. Chellube and F. I. Abdulrahman (2012). Assessment of Pollutants in Water and Sediment Samples in Lake Chad, Baga, Northeastern Nigeria. Journal of Environmental Protection, 3 (11).

[9] APHA (1992). Standards methods for analysis of water and wastewater. 18th ed. American Public Health Association, inc., Washington D. C.

[10] B. Simpi, S. M. Hiremath, K. N. S. Murthy, K. N. Chandrashekarappa, A. N. Patel and E. T. Puttiah (2011). Analysis of Water Quality Using Physicochemical Parameters Hosahalli Tank un Shimoga District, Karnataka, India. Global Journal of Science Frontier Research.

[11] E. Bernard and N. Ayeni (2012). Physicochemical Analysis of Groundwater Samples of Bichi Local Government Area of Kano of Nigeria. World Environment, 2 (6): 116-119.

[12] S. J. Chandne (2014). Physicochemical Parameters of the Drinking Water of some Villages of Yavatmal District, Maharashtra (India). Journal of Science Research and Studies, $1-4$.

[13] I. Y. Chindo, E. Karu, I. Ziyok and E. D. Amanki (2013). Physicochemical Analysis of Groundwater of Selected Areas of Dass and Ganjuwa Local Government Areas, Bauchi State, Nigeria. World Journal of Analytical Chemistry, 1 (4): 73-79.

[14] NSDWQ, (2007). Nigerian Standards for Drinking Water Quality. NIS 554, Standard Organization of Nigeria, Lagos, 30 .

[15] WHO (2006). Guidelines for Drinking Water Quality. 3rd Edition, WHO Press, Geneva, 398.

[16] Umara Z., Adamu U. B., Mustapha A. I. and Abdulqadir B. B. (2016). Physicochemical Analysis of Drinking Water from Selected Boreholes in Maiduguri Metropolis, Nigeria. International Journal of research, 3 (18): 1954-1958.

[17] H. C. Kataria, M. Gupta, M. Kumar, S. Kushwaha, S. Kashyap, S. Trivedi, R. Bhadoriya and N. K. Bandewar (2011). Study of Physicochemical Parameters of Drinking Water of Bhopal city with Reference to Health Impacts. Current World, 6 (1): 95-99.

[18] K. G. Chaudhari (2013). Studies of Physicochemical Parameters of Water Samples. Der Chemica Sinica, 4 (6): 2931.

[19] N. Sharma and Y. K. Walia (2016). Water Quality Investigation by Physicochemical Parameters of Satluj River (Himachal, Pradesh India). Current world environment, 12 (1): $174-180$.

[20] M. S. Hamaidi, and F. H. Chergui (2014). Physicochemical Quality of Boreholes used as a Source of Public Supply in Arib (Ain-Defla, Algeria). European academic research, 1 (12): 5379-5392.

[21] EPA, (2003). U. S. Environmental Protection Agency safe drinking Water act. EPA 816-F-03-016. 
[22] S. Chandra, A. Singh, P. K. Tomar and A. Kumar (2011) Evaluation of Physicochemical Characteristics of Various River Water of India. E- Journal of chemistry, 8 (4): 15461555.

[23] N. Gupta, P. Pandey and J. Hussain (2017). Effect of Physicochemical and Biological Parameters on the Quality of River Water of Narmada, Madhya Pradesh, India. Water Science, 31: 11-23.

[24] Saana et al., (2016). Assessment of the Quality of Groundwater for Drinking Purposes in the Upper West and
Northern Regions of Ghana. Springerplus, 5:2001. DOI:10.1186/s40064-016-3676-1.

[25] A. Magadum, P. Patel and D. Gavali (2017). Assessment of Physicochemical Parameters and Water Quality Index of Vishwamitri River, Gujarat, India. International Journal of Environment, Agriculture and Biotechnology, 2 (4): 15051510 .

[26] WHO (2011). Drinking water standards and health advisories office of water U. S. Environmental Protection agency Washington, DC. 